Nematophagous Fungi from Cattle Manure in Four States of Decomposition at Three Sites in Nova Scotia, Canada

Author(s): C. J. Mahoney and D. B. Strongman

Source: Mycologia, Vol. 86, No. 3 (May - Jun., 1994), pp. 371-375

Published by: Mycological Society of America

Stable URL: http://www.jstor.org/stable/3760567

Accessed: 17-06-2015 12:19 UTC

Your use of the JSTOR archive indicates your acceptance of the Terms \& Conditions of Use, available at http://www.jstor.org/page/ info/about/policies/terms.jsp

JSTOR is a not-for-profit service that helps scholars, researchers, and students discover, use, and build upon a wide range of content in a trusted digital archive. We use information technology and tools to increase productivity and facilitate new forms of scholarship. For more information about JSTOR, please contact support@jstor.org. 


\section{Nematophagous fungi from cattle manure in four states of decomposition at three sites in Nova Scotia, Canada}

\author{
C. J. Mahoney \\ D. B. Strongman ${ }^{1}$ \\ Biology Department, Saint Mary's University, Halifax, \\ Nova Scotia B3H 3C3, Canada
}

\begin{abstract}
New geographic distributions are reported for 18 species of nematophagous fungi from 36 samples of cow manure at three sites in Nova Scotia, Canada. Arthrobotrys flagrans was the most common species followed by Harposporium anguillulae and Myzocytium sp. The distribution of nematophagous fungi in manure in four different states of decomposition was examined. The greatest number of species and highest prevalence of fungi were in the most decomposed manure, while the fewest species and lowest prevalence were in the least decomposed manure. This correlated with increased prevalence of nematodes as the manure decomposed.
\end{abstract}

Key Words: abundance, diversity, fungal ecology, geographic records, Maritimes, nematode-destroying fungi

\section{INTRODUCTION}

Over 150 species of nematophagous fungi have been described from North America and many other geographic locations around the world (Gray, 1983; Gray et al., 1982). The biology of nematode-destroying fungi has been studied extensively (see Gray, 1987) and recently there has been renewed interest in these fungi because they have potential as biocontrol agents for plant and animal parasitic nematodes (Dackman et al., I992; Gronvold et al., I988; Kerry, I990). Researchers interested in nematophagous fungi have acknowledged that it is essential to obtain a basic knowledge of the ecology of these fungi (Cooke, I963; Gray 1987).

Manure contains high populations of nematodes and nematophagous fungi so ecological studies on nematode-destroying fungi have usually included this substrate (Barron, I977; Gray, 1983), but little information is available on the changes in species composition and prevalence of nematophagous fungi in manure as it decomposes.

\footnotetext{
${ }^{1}$ Author to whom correspondence should be addressed. Accepted for publication January 19, 1994.
}

In Canada, nematophagous fungi have been recorded from soil, plant material and dung from Ontario (Barron, I977) and Quebec (Estey and Olthof, I965), but no records of these fungi from Nova Scotia have been published. The purpose of this paper was to record the nematophagous fungi in cattle manure from Nova Scotia, Canada (NS), and to determine the species composition of these fungi in manure in different states of decomposition.

\section{MATERIALS AND METHODS}

Manure samples were collected on July 9, 1992 from the Kipawo Farm in Wolfville, NS $\left(64^{\circ} 20^{\prime} \mathrm{W}, 45^{\circ} 05^{\prime} \mathrm{N}\right)$; the Poole Farm in Brooklyn, NS $\left(64^{\circ} 00^{\prime} \mathrm{W}, 45^{\circ} 00^{\prime} \mathrm{N}\right)$, and the Elm Knoll Farm in Beaver Brook, NS $\left(63^{\circ} 25^{\prime} \mathrm{W}\right.$, $45^{\circ} 20^{\prime} \mathrm{N}$ ) (FIG. 1). At each farm three replicate samples of manure in four different states of decomposition (sample types) were collected in or near a manure pile. All manure piles sampled were composed of cattle manure between 6 months and $2 \mathrm{yr}$ old from top to bottom of the pile according to the farmers. The sample types at each site were designated FRESH, PILE, RUNOFF and SOIL. FRESH samples were from cow droppings less than $1 \mathrm{da}$ old and within $20 \mathrm{~m}$ of the manure pile, each replicate sample was taken from a different cow patty; PILE samples were taken from approximately half way up the manure pile, $5 \mathrm{~cm}$ into the pile; RUNOFF samples were taken from the liquid manure formed by rain leaching the pile and pooling near the base of the manure pile; and SOIL samples were collected from the top $5 \mathrm{~cm}$ of soil, $3 \mathrm{~m}$ from the base of the pile opposite the RUNOFF site. The sample types comprise a range from least decomposed (FRESH) to most decomposed (SOIL) manure. All samples were collected with a flame-sterilized garden trowel and placed in sterile sample bags. The samples were stored at 3-5 $\mathrm{C}$ until the nematodes and fungi were extracted.

The Baermann funnel method and baited plate method were used to extract nematodes and fungi from the samples (Barron, 1977). These methods are recommended for recovery of both predacious and endoparasitic fungal species (Bailey and Gray, 1989). Four subsamples of $20 \pm 0.5 \mathrm{~g}$ were taken from each of the three replicate samples of each sample type collected at the three sites. Nematodes extracted from 


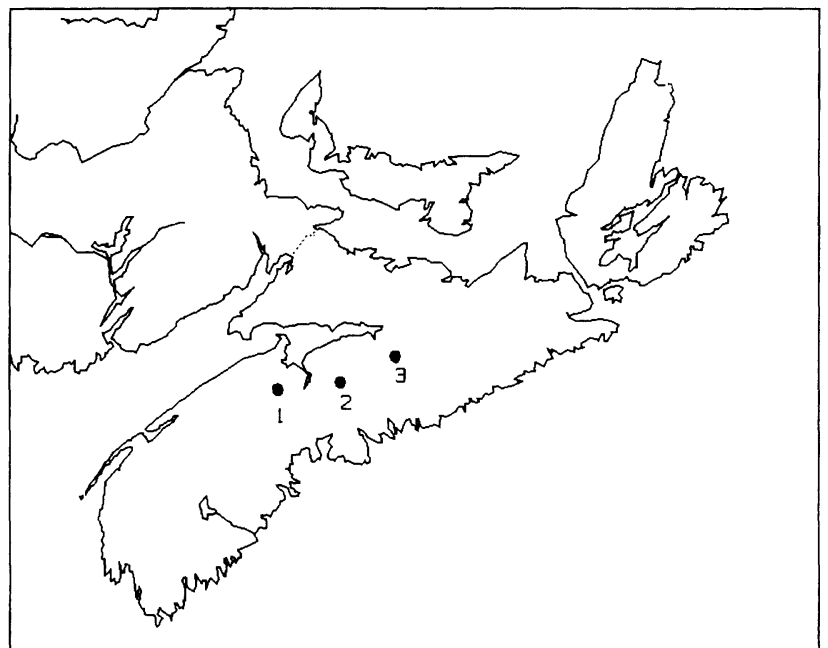

FIG. 1. Location of sampling sites in Nova Scotia, Canada.

the subsamples by the Baermann funnel method were placed on water agar plates (Difco Bacto agar, $15 \mathrm{~g}$ in $1 \mathrm{~L}$ distilled water). The prevalence of nematodes in each sample type was estimated by recording the presence or absence of nematodes extracted with Baermann funnels from the subsamples of each sample type at each site. No attempt was made to identify the nematode species but a variety of types were likely present based on differences in size and morphology of the nematodes observed.

For the baited plate method four subsamples of 1 $\pm 0.2 \mathrm{~g}$ each were taken from each sample and sprinkled on water agar plates baited with several hundred lab stock nematodes. The nematode stock culture originated from a single gravid female (Rhabditidae, probably a Rhabditis sp.) collected from manure and reared on pea soup mix sprinkled on agar as described in Barron (1977). A continuous culture was maintained by transferring nematodes to fresh plates of agar and pea soup mix every 2 wk.

All plates obtained from both the Baermann funnel and baited plate methods were placed in sealed plastic bags and incubated at $25 \mathrm{C}$ for a period of $7 \mathrm{wk}$ during which time weekly observations were made at $100 \times$ magnification using a dissecting microscope. Wet mounts were made from fungus-colonized nematodes, and the fungi were identified using Cooke and Godfrey (1964) and Schenck et al. (1977). The number of fungal species recorded from both extraction methods were combined for each subsample.

The total number of species present (species richness) at each site and for each sample type for all sites combined was recorded. The mean number of species per sample for each sample type was compared using a one-way analysis of variance (ANOVA). A Student-

TABLE I. List of fungi isolated from manure at three farms in Nova Scotia

\begin{tabular}{|c|c|c|c|c|}
\hline \multirow[b]{2}{*}{ Fungal species } & \multicolumn{3}{|c|}{ Farm } & \multirow[b]{2}{*}{ Abundance $(\%)^{\mathrm{a}}$} \\
\hline & Kipawo & Poole & Elm Knoll & \\
\hline \multicolumn{5}{|l|}{ Arthrobotrys arthrobotryoides } \\
\hline Lindau & $-\mathrm{b}$ & + & + & 2.1 \\
\hline Arthrobotrys conoides Drechsler & - & + & + & 5.6 \\
\hline Arthrobotrys flagrans Duddington & + & + & + & 26.0 \\
\hline Arthrobotrys longispora Soprunov & - & + & - & 0.7 \\
\hline Arthrobotrys musiformis Drechsler & + & - & - & 1.4 \\
\hline Arthrobotrys oligospora Fresenius & - & + & + & 2.8 \\
\hline Arthrobotrys oviformis Soprunov & + & - & + & 4.9 \\
\hline \multicolumn{5}{|l|}{ Arthrobotrys pyriformis (Juniper) } \\
\hline Schenck et al. & - & - & + & 2.8 \\
\hline Arthrobotrys robusta Duddington & + & + & - & 9.7 \\
\hline Arthrobotrys superba Corda & + & - & - & 0.7 \\
\hline Catenaria anguillulae Sorokin & - & + & - & 5.6 \\
\hline Cystopage sp. & + & + & + & 14.0 \\
\hline Drechmeria coniospora Drechsler & - & + & + & 1.4 \\
\hline Harposporium anguillulae Lohde & + & + & + & 25.0 \\
\hline Harposporium lilliputanum Dixon & + & + & + & 9.0 \\
\hline Myzocytium sp. & + & + & + & 20.0 \\
\hline Nematoctonus haptocladus Drechsler & - & + & - & 4.2 \\
\hline Unidentified deuteromycete & - & - & + & 2.8 \\
\hline Total no. of species present & 9 & 13 & 12 & \\
\hline
\end{tabular}

${ }^{a}$ (No. of petri plates with the fungus/144 plates observed) $\times 100$.

${ }^{\mathrm{b}}$ Species present $=+$; species absent $=-$. 
Newman-Keuls test was used to determine which means were significantly different.

The prevalence (\% occurrence/species) of all fungal species collected from each sample type for all three sites combined was determined by totalling the number of occurrences of each species in a sample type/ 36 (the maximum number of occurrences) then dividing by the total number of species (n) recovered from that type $\times 100$.

\section{RESULTS}

We recovered at least 18 different species of nematophagous fungi from the four sample types at three farms in Nova Scotia; 15 were identified to species, 2 to genus, and 1 was identified only as a deuteromycete because it produced trapping hyphae but no spores (TABLE I). The most common species recorded were Arthrobotrys flagrans, Harposporium anguillulae and Myzocytium sp. (TABLE. I). In addition to the fungi, we observed a spore-forming bacterial pathogen from the four sample types and at all three sites (abundance $=$ 7.6\%). Based on its spore characteristics and parasitic habit on nematodes the bacterium we observed likely belongs in the genus Pasteuria (Sayre, 1993).

There were some differences in the distribution of the fungal species among the three farms. None of the farms had all 18 species recorded and some species were found at only one site (TABLE I). The Poole farm showed the highest species richness with 13, next was Elm Knoll Farm with 12, and Kipawo Farm had 9 species (TABLE I).

The species distribution was different among the sample types at the three sites when the data were combined. The greatest species richness was in the SOIL type (16 spp.), while the fewest species were recorded in the FRESH type (4 spp.) (FIG. 2). Nematodes were more prevalent in SOIL than in the other sample types (FIG. 2) and increased fungal species richness correlated well with higher prevalence of nematodes $\left(\mathrm{r}^{2}=0.658\right)$.

Not only were there differences in the distribution of fungal species among the different sample types but the species composition and relative abundance differed too (TABLE II). More species had high abundance in the soil type (five species with number of occurrences $>10$ ) than in the others (TABLE II). The mean number of species recovered from a sample ( $\mathrm{n}$ $=9)$ in SOIL was significantly higher $(\mathrm{p}<0.01)$ than the means for the other types. The mean for RUNOFF was significantly higher than for FRESH, while the mean for the PILE type did not differ significantly from that for FRESH or RUNOFF (TABLE II).

When the abundance was adjusted for the total number of species in a sample type (no. occurrences/

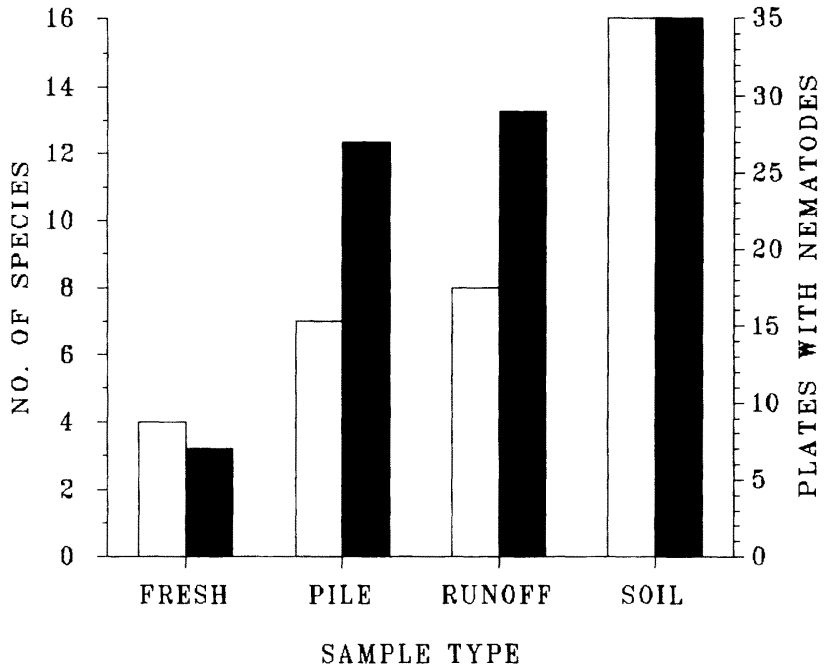

FIG. 2. Number of nematophagous fungal species and prevalence of nematodes recovered in each sample type for all sites combined $(\square=$ species richness; $\square=$ nematode prevalence).

no. of species) the data still showed an increase in prevalence from the FRESH to the SOIL type but little difference between the PILE and RUNOFF types (FIG. 3). When fungal prevalence is compared to nematode prevalence (FIG. 3), it appears that both fungi and nematodes increase in prevalence with increased manure decomposition. There was a strong correlation between the two variables $\left(\mathrm{r}^{2}=0.916\right)$.

\section{DISCUSSION}

The majority of fungi were identified to species with three exceptions. Isolates referred to as Myzocytium sp. were not identified further because there is too little variation among the species descriptions (Gray, 1984). An isolate was identified as Cystopage sp. based on its trapping of nematodes by sticky, yellow adhesive secreted from aseptate hyphae lacking differentiated trapping structures, chlamydospores or conidia. Estey and Olthof ( $\left.196_{5}\right)$ described a similar fungus from Quebec as "Mycelium 119," and Duddington (I954) referred to such a fungus as "Mycelium 186." Thirdly, a nematode trapping fungus with 3-dimensional adhesive nets was observed but no conidial structures were present, so it was identified only as a deuteromycete.

A comparison of species richness among the three farms revealed that they had roughly the same number of species. The species composition at each site differed with some species present at one farm only (TABLE I). The differences were few and the conditions at the farms similar so this likely represents normal variability that is expected in fungal populations. 
TABLE II. Abundance of fungal species isolated from manure in four states of decomposition for all farms combined

\begin{tabular}{|c|c|c|c|c|}
\hline \multirow[b]{2}{*}{ Fungal species } & \multicolumn{4}{|c|}{ Sample types ${ }^{\mathrm{a}}$} \\
\hline & FRESH & PILE & RUNOFF & SOIL \\
\hline Arthrobotrys arthrobotryoides & $0^{\mathrm{b}}$ & 0 & 2 & 1 \\
\hline Arthrobotrys conoides & 0 & 0 & 0 & 8 \\
\hline Arthrobotrys flagrans & 0 & 17 & 16 & 5 \\
\hline Arthrobotrys longispora & 0 & 0 & 0 & 1 \\
\hline Arthrobotrys musiformis & 0 & 2 & 0 & 0 \\
\hline Arthrobotrys oligospora & 0 & 0 & 1 & 3 \\
\hline Arthrobotrys oviformis & 2 & 0 & 0 & 5 \\
\hline Arthrobotrys pyriformis & 0 & 2 & 0 & 2 \\
\hline Arthrobotrys robusta & 1 & 0 & 1 & 12 \\
\hline Arthrobotrys superba & 0 & 1 & 0 & 0 \\
\hline Catenaria anguillulae & 0 & 0 & 0 & 8 \\
\hline Cystopage sp. & 1 & 0 & 3 & 16 \\
\hline Drechmeria coniospora & 0 & 0 & 0 & 2 \\
\hline Harposporium anguillulae & 0 & 7 & 2 & 27 \\
\hline Harposporium lilliputanum & 0 & 0 & 0 & 13 \\
\hline Myzocytium sp. & 0 & 0 & 12 & 17 \\
\hline Nematoctonus haptocladus & 0 & 3 & 0 & 3 \\
\hline Unidentified deuteromycete & 1 & 1 & 1 & 1 \\
\hline $\begin{array}{l}\text { Mean no. of species/sample } \\
\qquad(\mathrm{n}=9)\end{array}$ & $0.6 \pm 1.0 \mathrm{x}^{c}$ & $1.6 \pm 0.9 x y$ & $2.9 \pm 1.6 y$ & $7.2 \pm 1.9 z$ \\
\hline Percent occurrence/species & 3.3 & 12.5 & 12.8 & 21.8 \\
\hline
\end{tabular}

Six species recorded in our study, Arthrobotrys oligospora, A. conoides, A. musiformis, A. robusta, A. superba, Harposporium anguillulae and Cystopage sp., were common species reported by others (Duddington, 1951; Estey and Olthof, 1965; Gray, 1983). The most fre-

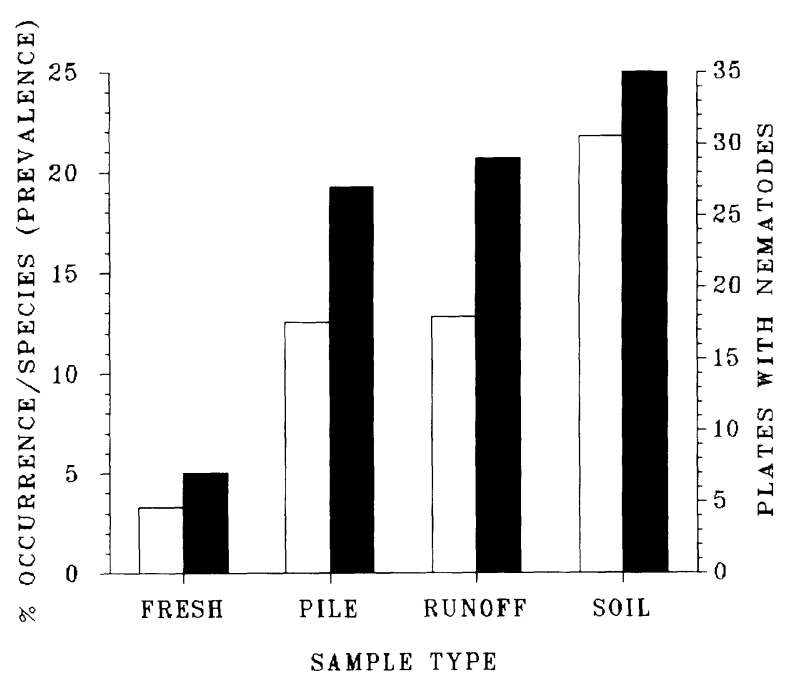

FIG. 3. Prevalence of nematophagous fungal species and nematodes in each sample type for all sites combined $(\square=$ fungal prevalence; $\mathbf{\square}=$ nematode prevalence). quently recorded species in our survey was Arthrobotrys flagrans, which was present in approximately $26 \%$ of all observations, followed by Harposporium anguillulae, in 25\% of the observations, and Myzocytium sp. in 20\% of the observations. Harposporium anguillulae was one of the most frequently recovered endoparasites in British soils (Duddington, 1951), and Myzocytium sp. was the most frequent endoparasite in Irish soils (Gray, 1983). Arthrobotrys oligospora was the most abundant species isolated in Quebec (Estey and Olthof, 1965). This fungus was present in only $2.8 \%$ of our observations, which was comparable with observations from Ireland (1.2\%) (Gray, I983). We found a relatively low prevalence and distribution of Catenaria anguillulae, while Barron (1977) found this species in over $90 \%$ of farmyard soil samples in Ontario.

Our data on species composition and prevalence from manure in Nova Scotia are more like the data from Irish and British soils than the data from Quebec and Ontario soils. The maritime climate in Nova Scotia provides physical conditions more like Britain or Ireland than Quebec and Ontario, which may account for the similar fungal species composition.

The change in species richness and prevalence from the least decomposed (FRESH) to the most decomposed (SOIL) (TABLE II, FIG. 3) suggests that manure 
is colonized by different nematophagous fungi as it decomposes. From our data it appears that few nematophagous fungi are present in manure when it is excreted so fungi probably colonize the manure from the soil or air, likely from spores dispersed by insects or nematodes. Factors, such as competition, and physical parameters that influence community structure in coprophilous saprophytic fungi are known to affect the nematophagous fungi too (Cooke, 1963 ). Our data show that the most decomposed manure (SOIL) contained more species and had the highest fungal prevalence compared to the other sample types (TABLE II, FIG. 3). Few species were found in FRESH manure. Arthrobotrys flagrans was most abundant in the PILE and RUNOFF sample types, but its occurrence declined in SOIL while the abundance of other species (H. anguillulae, Myzocytium sp. and Cystopage sp.) increased dramatically (TABLE II). These data suggest that succession occurs as manure decomposes.

The correlation between nematode prevalence and fungal species richness and prevalence suggests that these fungal populations are in part dependent on their nematode prey/hosts as in any predator-prey or parasite-host relationship. Our work also illustrates a trend for the increase in species richness and prevalence of a predator/parasite to lag behind the increase of the prey/host (FIGS. 2, 3), which is typical of most predator-prey relationships (Begon et al., 1990).

\section{ACKNOWLEDGMENTS}

This work was done by C. J. Mahoney as part of a B.Sc. (Honors) degree in the Biology Department at Saint Mary's University, Halifax, Nova Scotia, and was partially funded by a Natural Sciences and Engineering Council research grant to D. B. Strongman. We thank Dr. Gwyneth Jones, Maitland, N.S. for identifying the lab stock nematode to family.

\section{LITERATURE CITED}

Bailey, F., and N. F. Gray. 1989. The comparison of isolation techniques for nematophagous fungi from soil. Ann. Appl. Biol. 114: 125-132.

Barron, G. L. 1977. The nematode destroying fungi. Topics in mycobiology, No. 1. Canadian Biological Publications, Ltd., Guelph, Ontario. 140 pp.

Begon, M., J. L. Harper, and C. R. Townsend. 1990. Ecology: individual, populations and communities. Blackwell Scientific Publications, Boston, Massachusetts. 945 pp.

Cooke, R. C. 1963. Ecological characteristics of nematodetrapping Hyphomycetes: I. Preliminary studies. Ann. Appl. Biol. 52: 431-437.

destroying fungi. Trans. Brit. Mycol. Soc. 47: 61-74.

Dackman, C., H. B. Jansson, and B. Nordbring-Hertz. 1992. Nematophagous fungi and their activities in soil. Pp. 95-130. In: Soil biochemistry. Eds., G. Stotzky and J. M. Bollag. Marcel Dekker, New York.

Duddington, C. L. 1951. The ecology of predacious fungi. I. Preliminary survey. Trans. Brit. Mycol. Soc. 34: 322331.

-1954. Nematode-destroying fungi in agricultural soils. Nature 173: 38-39.

Estey, R. H., and T. H. A. Olthof. 1965. The occurrence of nematophagous fungi in Quebec. Phytoprotection 46: $14-17$.

Gray, N. F. 1983. Ecology of nematophagous fungi: distribution and habitat. Ann. Appl. Biol. 102: 501-509.

- 1984. The distribution of predatory and endoparasitic nematophagous fungi in Ireland. Bull. Irish Biogeogr. Soc. 7: 19-37.

- 1987. Nematophagous fungi with particular reference to their ecology. Biol. Rev. 62: 245-304.

— C. H. E. Wyborn, and R. I. L. Smith. 1982. Nematophagous fungi from the Maritime Antarctic. Oikos 38: 194-201.

Gronvold, J., P. Nansen, S. A. Henriksen, J. Thylin, and J. Wolstrup. 1988. The capability of the predacious fungus Arthrobotrys oligospora (Hyphomycetales) to reduce numbers of infective larvae of Ostertagia ostertagi (Trichostrongylidae) in cow pats and herbage during the grazing season in Denmark. J. Helminthol. 62: 271280.

Kerry, B. R. 1990. An assessment of progress toward microbial control of plant-parasitic nematodes. J. Nematol. 22: 621-631.

Sayre, R. M. 1993. Pasteuria, Metchnikoff, 1888. Pp. 101111. In: Bacillus subtilis and other gram-positive bacteria: biochemistry, physiology, and molecular genetics. Eds., J. A. Hoch and R. Losick. Amer. Soc. Microbiol., Washington, D.C.

Schenck, S., W. B. Kendrick, and D. Pramer. 1977. A new nematode-trapping hyphomycete and a reevaluation of Dactylaria and Arthrobotrys. Canad. J. Bot. 55: 977-985. 